\title{
A COSMOLOGIA DE AGOSTINHO DE HIPONA
}

\author{
The Cosmology of Augustine of Hippo
}

João Eduardo Pinto Basto Lupi ${ }^{1}$

\begin{abstract}
RESUMO: Agostinho é quase sempre estudado como o "homem teológico" que em tudo via a presença e a ação divinas. Mas isso não o impedia de olhar o mundo físico à sua volta, e de prestar atenção às propriedades da terra, da água, do fogo, e aos movimentos dos astros. Tinha especial predileção pelos cálculos numéricos, e pela questão da natureza do tempo. A essas observações dispersas pode parecer um tanto impróprio chamar cosmologia, mas ela existe na medida em que, por trás desse modo de observar, há uma concepção de universo que é ao mesmo tempo teológica, antropológica, e concreta, em que, acima de tudo, o cosmo ostenta ordem e beleza, e é um sinal do Criador.
\end{abstract}

PALAVRAS-CHAVE: Agostinho; Cosmologia; Mundo físico; Ordem; Universo.

ABSTRACT: Usually, Augustine is studied as a theological man, who in all things sees the presence and action of God. However, this consideration was not for him an obstacle to take attention to the physical world around him, and to the properties of water, fire, and other things, besides the movement of the stars. Some of his main interests were numbers calculations, and the nature of time. To those scattered observations of Augustine is not quite correct to call a cosmology, but it exists in the sense that, behind that way to consider the universe, there is a theological method which is a view that includes, at the same time, anthropological and physical aspects. Besides, the cosmos displays order, beauty, and it is a sign of the Creator.

KEYWORDS: Augustine; Cosmology; Physical world; Order; Universe.

\section{A Estrutura do universo}

\section{Deus e o universo}

O que mais se destaca nas concepções cosmológicas de Agostinho é o conjunto de relações entre Deus e o universo. Deus é o Criador de todas as coisas, e, sendo Ele

\footnotetext{
${ }^{1}$ Doutor em filosofia pela Universidade Católica de Portugal (UCP) e professor emérito da Universidade Federal de Santa Catarina (UFSC). E-mail: lupi@cfh.ufsc.br
} 
Supremo Bem, tudo o que Ele cria é bom, embora haja que admitir graus na bondade das coisas; por outro lado criar significa tirar do nada, de "algo" que não era algo, e também, não havendo nada material, não havia tempo, mas só eternidade, a ausência de tempo, por não haver movimento de coisas materiais. Mas Ele não só cria, como cuida do que cuidou (providência, presciência). Além disso se Deus é Supremo, ou seja, o Ser Absoluto, não pode haver outro criador senão Ele, e consequentemente não existe um criador do mal. Deus cria pela Razão, pelo Logos, isto é, Ele cria o mundo numa perfeita racionalidade, e nesse caso tudo está numa perfeita ordem objetiva, mesmo que subjetivamente nos pareça que há desordem: não há no universo nem desordem, nem acaso - o qual seria devido a um agente não divino. Neste contexto teológico não fazem sentido perguntas como: o que Deus fazia antes de criar o mundo? Porque é que Deus não criou o mundo antes? Deus criou tudo o que podia existir? Agostinho responde a estas e outras perguntas sempre dentro de uma doutrina que se pode considerar mais como Teodiceia do que como Cosmologia, uma vez que o princípio fundamental das perguntas e respostas não está na constituição do mundo, mas na doutrina acerca de Deus, Uno e Perfeito. De modo semelhante não se pode falar acerca da presciência e predestinação por parte de Deus, porque não estando Deus no tempo, mas num ato único, eterno, imutável e permanente, Deus não prevê ou não sabe com antecedência o que vai acontecer, mas simplesmente vê e sabe tudo num ato só de conhecimento do mundo. Este ponto de vista, ou estas concepções acerca da relação entre Deus e o mundo, não sendo propriamente cosmológicas, devem ser tidas em conta quando se descreve e analisa a concepção do mundo material própria de Agostinho, que é o que mais restritamente vamos considerar como Cosmologia; geralmente tivemos em consideração apenas o mundo material inerte, ou não vivo, exceto em uma ou outra questão, como as razões seminais, e o problema dos animais nocivos, para não se perder de vista o conjunto do cosmo.

Porém, ao procurar as ideias e concepções de Agostinho a respeito da constituição do universo material inerte - o que, propriamente falando, é cosmografia - nos deparamos com uma outra atitude que é própria do Autor, e que não é cosmológica, mas antropológica. Neste caso o exemplo mais conhecido é a frase de Agostinho a respeito do tempo, e que se resume a dizer: "sei o que é mas não sei explicar"². A partir daqui quase tudo o que Agostinho diz sobre o tempo tem mais a ver com a percepção do tempo (antropologia) do que com o tempo em si. A questão começa a definir-se de um ponto de

\footnotetext{
${ }^{2}$ Confissões 11, 14, 17. Citaremos Agostinho sempre em língua portuguesa. Nos textos que só temos em inglês (NPNF: Nicene and Post Nicene Fathers) a tradução é nossa.
} 
vista mais limitadamente referente ao cosmo quando Agostinho analisa o tempo, na formulação aristotélica, pelo antes e depois: se o passado já não existe, e o futuro ainda não existe, e o presente está continuamente deixando de existir, parece que se deve dizer que o tempo não existe ${ }^{3}$. Mas logo em seguida Agostinho volta à sua antropologia: o tempo é uma distensão da alma, na medida em que a nossa memória conserva imagens que lhe estão presentes, e a mente mantém expectativa e antecipações que tornam presente o futuro ${ }^{4}$. Em suma: pelo dito até aqui é claro que o mundo não existe independentemente de Deus, e ele não tem sentido se o ser humano não o experimenta e vive, isto é, o significado do mundo físico ou é teológico, ou é antropológico (eventualmente biológico) - em si mesmo é como se não existisse.

Vamos ver se este ponto de vista subjetivo acerca do universo se apoia em alguma visão objetiva, mesmo que parcial ou incompleta, sobre o que as coisas são e como são. Em poucas palavras: $O$ que é que as coisas são na sua realidade factual, e como estão organizadas?

\section{O universo é belo}

Todas as criaturas são boas "quando saem das mãos de Deus" (tudo é certo em saindo das mãos do Autor das coisas. Rousseau, Emílio), mas nem sempre há harmonia entre as coisas criadas; as criaturas que não têm harmonia com as outras são lançadas na terra para se harmonizarem com o que é inferior, e elas têm o seu próprio céu, nebuloso e com ventanias 5 .

O mundo é belo e bom. O universo é belo mesmo quando algumas de suas partes se corrompem e destroem.

Tudo o que existe mantem proporção em sua aparência e modo de ser (...) e é ordenado de tal modo que as coisas mais fracas se apoiam nas mais firmes (...) e assim as coisas terrestres se harmonizam com as celestes, sujeitas como estão às que lhe são superiores. Mesmo no que é decadente e transitório existe certa beleza temporal, de tal modo que nem o que morre, se altera ou degrada prejudica a aparência e a ordem da criação universal. ${ }^{6}$

$\mathrm{Na}$ retórica considera-se belo um discurso que faz uso das figuras de linguagem, particularmente dos termos contrários, colocados, ou ditos, em forma de antítese. Assim

\footnotetext{
${ }^{3}$ Confissões ib. e 11,15, 19 a 20.

${ }^{4}$ Ib. 11, 20, 26 e 11, 26, 33.

${ }^{5}$ Confissões 7, 13, NPNF 2, 110.

${ }^{6}$ A Natureza do Bem. Cap. 8, NPNF 4, 352-353.
} 
também os seres que povoam o universo se apresentam em oposições de contrários, o que contribui para a beleza do mundo - como se houvesse uma eloquência das coisas ${ }^{7}$.

Porém o mundo em sua beleza e grandiosidade deve ser admirado, mas não por si mesmo: sempre se deve ascender do material ao espiritual.

Há aqueles que ficam observando a grandeza, a beleza e os poderes das criaturas, mas ficam por aí, e não encontraram o Criador". Eles perdem tempo em disputas, investigações e medidas (...); procuram o curso das estrelas, os intervalos dos planetas, os movimentos dos corpos celestes, de maneira a calcular com exatidão os eclipses do sol e da lua, e prever qual o dia e hora, e a porção dos corpos que se ocultarão, e ainda querem saber quantas são as estrelas, e seus movimentos. Muito trabalho, muita atividade mental. Mas o Criador não estava longe, e no entanto não o encontraram. Tu não te preocupes se não sabes essas coisas, basta que reconheças a beleza do mundo e a inteligência do Criador ${ }^{8}$.

Noutro sermão Agostinho é ainda mais explícito: "O mundo é amado, mas devemos preferir Aquele por quem o mundo foi feito. O mundo é grande, mas maior é Aquele por quem o mundo foi feito. Belo é o mundo, mas mais belo é Aquele que o fez. Doce é o mundo, mas mais doce é Aquele que fez o mundo. O mundo é mau e bom é Aquele por quem foi feito o mundo. E como podemos explicar isto?"

\section{A ordem do mundo}

O mundo é belo porque tem uma ordem, uma harmonia: tudo o que Deus cria tem ordem e beleza. "A ordem é aquilo pelo qual são conduzidas todas as coisas que Deus estabeleceu"10.

“A ordem domina, ainda, na música, na geometria, no movimento dos astros, nas leis dos números, de tal maneira que, se alguém desejar ver como que a fonte dela e o seu próprio santuário, ou a há-de encontrar nestes, ou será conduzido através deles sem qualquer erro"11. "A própria ordem é em si um bem ou provém do bem - nunca houve nem haverá alguma vez coisa alguma sem ordem"12.

Mas em que é que se baseia a ordem para fazer com que o mundo seja belo? A ordem do mundo baseia-se na razão: “A razão é a moção da mente capaz de distinguir e relacionar as coisas que se aprendem, "mas nem todos os homens conseguem fazer dela

\footnotetext{
${ }^{7}$ Cidade de Deus 11, 18, Gulbenkian 1031, NPNF 2, 215.

${ }^{8}$ Sermões sobre as lições do NT 18, 1 e 2 NPNF 6, 314.

${ }^{9}$ Sermão sobre as lições do NT 46, 4 NPNF 6, 410.

${ }^{10}$ Diálogo sobre a Ordem 1, X 28, p. 129.

${ }^{11}$ Diálogo sobre a Ordem 2, V, 14, p. 169.

12 Ib. 2, 23, p. 183.
} 
uso correto ${ }^{13}$. Agostinho discorre então num estilo perfeito, e de certo modo sublime, imaginando a razão à procura do belo:

A partir daqui, aquela razão quis lançar-se à contemplação ditosíssima das próprias coisas divinas. Mas para que não caísse do alto, procurou degraus, e ela própria construiu para si um caminho e uma ordem através das suas capacidades. Na verdade, desejava aquela beleza que, só e simples, pode ser contemplada sem estes nossos olhos. ${ }^{14}$

Mas, pouco a pouco, Agostinho vai descobrindo e explicando que a mesma razão que está na mente é a que está no cosmo: a razão

em seguida avançou para os recursos dos olhos. Percorrendo com o olhar a terra e o céu apercebeu-se de que nada lhe agradava senão a beleza, e, na beleza, as figuras, nas figuras, as proporções, nas proporções, os números. E ela investigou consigo mesma (...). Estas coisas que ela tinha distinguido e disposto remeteu para uma disciplina a que chamou geometria. O movimento do céu impressionava-a muito e instigava-a a que o considerasse com toda a atenção. Também aí, através das alternâncias sempre constantes dos tempos, do curso exato e definido dos astros, das distâncias fixas dos intervalos, entendeu que não havia nada que dominasse senão aquela proporção e os números (...) e gerou a astronomia". ${ }^{15}$

Continuando a sua busca, a razão examinou todas as coisas e percebeu "que tudo aquilo de que ela fosse capaz era pelos números. Tocou-a uma espécie de prodígio (quoddam miraculum) e começou a suspeitar que talvez fosse ela o próprio número pelo qual todas as coisas eram numeradas(...)"16.

Agostinho lança a ideia de que a razão rege toda a ordem, tanto a mental humana como a do universo, e que a beleza se encontra na realização da ordem racional na matéria, ou seja, tanto a ordem como a beleza residem no número, e que número e ordem são como que a mesma coisa. Mas retorna à sua ideia principal: o mundo real é o mundo vivido, e a razão que ordena o mundo é a razão humana, não como razão criadora, mas como razão que se percebe a si mesma no mundo.

Mas há algo mais, além do número, para constituir a ordem e beleza do universo: todas as coisas que Deus faz são regidas pela medida, o número e a ordem, e a maior beleza está no conjunto das partes bem ordenadas ${ }^{17}$. A ordem é algo peculiar, pois numa ordem completa até as ausências aperfeiçoam o conjunto, como os silêncios na música, em intervalos adequados, e as sombras na pintura: "Os intervalos de silêncio, embora sejam privações de vozes (se) são bem ordenados por aqueles que sabem cantar, conferem

\footnotetext{
${ }^{13}$ Ib. 2 XI 30, p. 197.

${ }^{14}$ Ib. 2 XIV 39, p. 209.

${ }^{15} \mathrm{Ib} .2 \mathrm{XV}$ 42, p. 213.

${ }^{16} \mathrm{Ib} .2 \mathrm{XV}$ 43, p. 215.

${ }^{17}$ Sobre o Genesis contra os maniqueus 1, 21, 32, p. 531.
} 
suavidade a todo o canto. Também as sombras que fazem ressaltar as partes mais importantes nas pinturas agradam, não pela beleza, mas pela ordem"18.

Porém logo mostra como, sendo este o movimento principal (o mundo vivido ou percebido) o movimento inverso é indispensável, ou seja, sem conhecer o mundo objetivo não se conhece nem a alma nem Deus: desconhecendo

o que é o nada, o que é a matéria informe, o que é o ser formado sem vida, o que é o corpo, o que é a forma no corpo, o que é o lugar, o que é o tempo, o que é no lugar e o que é no tempo, o que é o movimento segundo o lugar, o que é o movimento não segundo o lugar, o que é o movimento estável, o que é o evo, o que é não ser nem no lugar nem em parte alguma e o que é fora do tempo e sempre, o que é ser em nenhuma parte e não ser em nenhuma parte, o que é nunca ser e nunca não ser; (... $)^{19}$.

Agostinho mostra aqui que tem perfeito conhecimento de quais são as questões que a Filosofia clássica se colocava acerca do cosmo e particularmente do espaço e do tempo; além disso, considera que ter em conta essas questões e conhecê-las (pelo menos numa abordagem inicial) é indispensável "na investigação das coisas divinas... para que elas sejam não só contempladas, (mas) entendidas e conservadas" ${ }^{20}$. Com efeito, diz ele mais adiante "neste mundo sensível deve examinar-se com veemência o que é o tempo e o lugar" ${ }^{21}$ porque considerado dentro do conjunto é muito melhor e deleita mais.

Mas sobre o espaço Agostinho fala pouco: "Lidamos com os que pensam, como nós, que Deus é um ser incorpóreo, criador de todas as naturezas distintas da sua”. Para Agostinho a substância divina não está circunscrita a um lugar, "não é delimitada nem está fora do universo. (...) Não há senão um único mundo, formando sem dúvida uma massa corpórea, imensa, mas limitada, e circunscrita no seu lugar”. Os espaços possíveis a Deus são infinitos, mas o universo está num lugar definido, e não noutro ${ }^{22}$.

\section{Os Números/A Geometria}

O número representa ou evidencia a ordem do mundo, portanto quando ele é sacralizado, ou elevado a uma ordem superior, é o universo que é elevado. Dito de outro modo: a estrutura material do universo contém em si a potência para ser espiritualizado, ou para evidenciar, pela alegoria, a espiritualidade e a divindade que está latente na matéria, à espera de que nós a descubramos e interpretemos. Mas será que esta explicação

\footnotetext{
${ }^{18}$ Comentário Literal ao Genesis inacabado, 5, 25, p. 612.

${ }^{19}$ Ib. 2 XVI 44, p. 215.

${ }^{20} \mathrm{Ib}$.

${ }^{21}$ Ib. 2, XIX 51, p. 227.

${ }^{22}$ Cidade de Deus XI, 5, Gulbenkian 998.
} 
(divagação) se encontra em Agostinho? Parece que sim, de muitos modos e muitas vezes. Quando Jesus disse: "um de vós é o diabo" 23 , mas eu vos escolhi doze - faz com isso que o número doze se torne sagrado, diz Agostinho $^{24}$ e o fato de um dos doze ser afastado não diminui a sacralidade desse número; ele era sagrado porque a missão dos doze apóstolos era pregar a Trindade pelos quatro cantos do mundo $(3 \times 4=12)$. Portanto a natureza sagrada de um número não está em si mesmo, mas na sua relação com alguma palavra ou evento da Escritura, e particularmente com a palavra de Jesus.

Cada vez que se depara com um número - por exemplo: 46 anos demorou a construção do templo ${ }^{25}$ - Agostinho se compraz em decompor, comparar e mostrar a relação desse cálculo com uma ideia, ou conjunto de ideias. Mas também, em vez de decompor o número, pode compor, somando com outro, ou outros. Assim o número 40 está associado com jejum (Moisés, Elias, Jesus) que celebramos na Quaresma; mas, na parábola, ao receber o prêmio (denarius) se acrescenta 10 a 40, e temos a Quinquagésima (Pentecostes), que celebramos com alegria depois da Páscoa ${ }^{26}$. Portanto os números têm qualidades que permitem fazer deles os degraus, ou a base, para alegorias espirituais.

Voltando aos doze: ao falar dos apóstolos, que, com a morte de Judas, eram só onze, Agostinho diz que era necessário repor o número, que é "um número consagrado" (sacratum illum numerum). O número 12 tinha tal importância mística que tornava necessário escolher outro apóstolo para "conservar o símbolo espiritual desse número"27.

Tal como nos outros temas referentes ao mundo físico, quando trata de números Agostinho prefere mostrar e descrever as alegorias que se fazem a partir deles, nomeadamente no Antigo Testamento: os 7 dias da Criação, os 10 Mandamentos, a data da Páscoa, os jejuns de 40 dias, e muitos outros exemplos. Mas salta à vista não só a extensão (quantidade de páginas) em que Agostinho desenvolve tais explicações, mostrando o seu prazer em lidar com números, mas ainda a facilidade com que faz alguns cálculos, denunciando um estudo cuidadoso de aritmética ${ }^{28}$.

Quanto à ciência dos números ${ }^{29}$ é evidente que ela não foi inventada pelos homens, diz Agostinho, porque as suas leis, ou regras, são imutáveis, pois "não está no poder de ninguém" fazer ou desfazer as leis dos quadrados, ou da multiplicação e divisão; e

\footnotetext{
${ }^{23}$ Jo 6,70 .

${ }^{24}$ Jo 27,10

${ }^{25}$ Jo $10,11-12, N P N F 7,73$.

${ }^{26}$ Jo $17,4, N P N F 7,112$.

${ }^{27}$ A harmonia dos Evangelhos/De Consensu Evangelistarum. NPNF 6, Livro 3, cap. 25, item 71, p. $216 \mathrm{~b}$.

${ }^{28}$ Carta 55, cap. 14, NPNF 27-31.

${ }^{29}$ Doutrina Cristã 2, 39 /46p. 145, NPNF 2, 38/56, p. 553.
} 
continua dizendo que essas leis da Matemática valem não só para si mesmas, e sem contestação, mas são fundamentais para outras ciências como a Geometria e a Música. Vejamos alguns dos cálculos aritméticos feitos por Agostinho e sua relação com determinada ordem do mundo.

No meio de um dos tratados de mais sutil teologia, o da Trindade, aparecem parágrafos longos sobre certas leis ou composições aritméticas, que Agostinho explica, e depois aplica à simbologia numérica da Bíblia. Começa por comentar a formação do número 6 $(1+2+3)$ considerado perfeito, e seu primeiro aparecimento nos seis dias da Criação, reaparecendo o 6 em outros eventos da história de Israel, e do Evangelho. Continua explorando as combinações e alegorias dos números, aplicados agora ao ciclo anual, e ao ciclo da lua, à divisão em meses, aos anos bissextos, e finalmente à divisão do dia em horas. Em todos os seus cálculos Agostinho mostra certa complacência (talvez prazer) em brincar com os números, e facilidade, quase familiaridade, em fazê-lo. Como epílogo ainda procura breves aplicações do número 6 à vida e paixão de Cristo $^{30}$.

Ao explicar, e repetir, que o número 6 é perfeito, Agostinho pretende atingir pelo menos dois objetivos: que a criação é perfeita "porque" (ou: essa perfeição está significada em) é simbolizada pelo número seis, dos dias em que se desenrolou; e porque, da consideração dos números - que o autor desenvolve longamente através de divisões, somas e multiplicações - quer chamar a atenção para o que está além dos números, que é o seu Criador. Mas, se foi bem sucedido em demonstrar os vários tipos de números, e de perfeição de números, não conseguiu explicitar a "superação" dos números, ou algo que parece pretender: uma mística implícita na combinação dos números. São tão variados, embora não complicados, os cálculos, com tantos números, que o leitor suspeita que Agostinho quer chegar mais longe, a outro patamar, mas fica pelo caminho ${ }^{31}$. Como ele mesmo diz, ao comentar a frase: "Tudo dispuseste com medida, número e peso"32: "É algo grande e a poucos concedido elevar-se sobre todas as coisas que podem ser medidas, para ver uma medida sem medida; elevar-se sobre todas as coisas que podem ser enumeradas, para ver um número sem número; elevar-se sobre todas as coisas que podem ser pesadas, para ver um peso sem peso" ${ }^{33}$.

\footnotetext{
${ }^{30}$ Sobre a Trindade 4, 4-5. NPNF 3, 73-74.

${ }^{31}$ Com. Genesis 4, 2, 2-6, p. 118-122.

${ }^{32} \mathrm{Sb} \mathrm{11,20.}$

${ }^{33}$ Ib. 4.3.8, p. 123.
} 
No Comentário contra Maniqueus ${ }^{34}$ ao falar dos animais nocivos e dos inúteis Agostinho amplia esta consideração: "Eu confesso que ignoro porque foram criados os ratos e as rãs ou as moscas ou os vermes, mas percebo que todas as coisas são belas no seu gênero (...)". E continua dizendo que em todos os animais observa que seus membros têm medidas, números e ordem que concorrem: "para a unidade harmônica dos mesmos. Não entendo de onde procedem, mas entendo de onde procedem suas medidas, números e ordem que têm seu fundamento na própria sublimidade imutável e eterna de Deus (...)". Portanto, conclui ele, com relação aos animais: "faze uso dos úteis, acautela-se dos perigosos, deixa de lado os supérfluos. Mas em todos, ao observares as medidas, os números e a ordem, busca o artífice. Não encontrarás outro a não ser a suprema medida, o supremo número e a suprema ordem, ou seja, Deus".

Finaliza este item com uma comparação que parece ser em tom de mofa, ou zombaria, algo raro no sério teólogo de Hipona: “Assim, talvez, obterás frutos mais abundantes ao louvar a Deus na pequenez da formiga, do que ao passar o rio no lombo de um grande animal de carga" 35 .

Continuando com os números: falando da primeira grande pescaria no lago, Agostinho diz que o número de peixes é pequeno, comparado com a profecia de Elias (Lc 5, 1-11; I Re 19,18). Agostinho, para demonstrar o que pretende, parte do número $17(10+7)$ e vai adicionando dígitos em sucessão ascendente. O número 17 compõe-se de 10 (dos dez mandamentos da Lei) e de 7 (dos dons do Espírito Santo). Examinando esse número verificamos, diz Agostinho, que ele contém tudo o que diz respeito à Ressurreição, ao Reino do Céu, e à vida eterna. Porém, ao adicionar, um por um, os números que se contêm em $17(1+2+3+4 \ldots)$ chega-se a 153 , o número de peixes da pescaria, representando milhares de milhares de santos ${ }^{36}$. O cálculo, aqui resumido, desenvolve-se ao longo de muitas linhas, e se primeiro admiramos a paciência do autor em explicar tão detalhadamente a sua alegoria, depois nos convencemos de que Agostinho não só tem prazer em fazer cálculos aritméticos, como confia na sua capacidade de demonstração; ou seja, Agostinho desenvolve uma verdadeira retórica matemática, cujo poder demonstrativo se apoia, por um lado, na lógica da alegoria, e, por outro na fundamentação do valor da matemática como estrutura abstrata do mundo. Nestes cálculos Agostinho não faz um jogo (algo lúdico) no sentido de brincadeira, livre e descomprometida; pelo

\footnotetext{
${ }^{34}$ Comentário contra Maniqueus 1, 16, 26, p. 524-525.

${ }^{35} \mathrm{Ib}$.

${ }^{36}$ Exposição sobre os Salmos 50, 9, NPNF 8, $181 \mathrm{ab}$.
} 
contrário, seu jogo é o jogo do mundo, em que a estrutura material está envolvida na ação humana, e tem o valor e a seriedade da coerência básica dos elementos do cosmo, e da relação verdadeira entre essa coerência dos elementos, as histórias e a História da Humanidade, e a coerência da complexidade da vida espiritual. A alegoria não é algo que se faz arbitrariamente, ela tem uma forte razão de ser.

O número sete merece diversas vezes a atenção de Agostinho: "Deus não santificou o primeiro dia da criação (nem os demais dias) mas santificou o sétimo dia" ${ }^{37}$. Este número sete, segundo o testemunho dos documentos da sabedoria espiritual que aos homens foram dados, significa os dons do Espírito Santo; a partir daqui Agostinho apresenta um cálculo aritmético somando números em ordem crescente dos dígitos até chegar ao número de peixes pescados pelos apóstolos, e ao dia da Ascensão do $\operatorname{Senhor}^{38}$, mostrando, por alegorias, como se chega às realidades espirituais. Ao falar do simbolismo do número 7 e sua aplicação diz Agostinho: "Sete deve ser colocado naquilo que é sempre, porque o curso total do tempo roda num círculo de sete dias que vão e retornam"39.

O número dez é um número perfeito $(1+2+3+4=10)$ e multiplicado pelo 4 , das 4 estações, dá 40, o número que aparece muitas vezes na Escritura para ressaltar a importância de um evento: jejum, êxodo no deserto, o período entre a Ressurreição e a Ascensão de Jesus. Já o número 77 significa a absolvição dos pecados: 10 (perfeição) x 7 (criação) é ultrapassado pelo 11 x 7, ou seja, 77 significa passar além da justiça, que é o perdão dos pecados ${ }^{40}$.

Os cálculos que Agostinho faz com os números são pouco mais do que simples operações de aritmética elementar (somas e subtrações, multiplicações e divisões) mas as alegorias que lhes correspondem são mais complicadas e menos evidentes. Por exemplo: o que é que um certo homem, doente, tinha a ver com o número 38 ? É porque a perfeição da Lei, diz o intérprete, está no 40 (os dez mandamentos x os 4 cantos do mundo), mas àquele homem faltam dois mandamentos da Lei, donde $40-2=38$, indicando fraqueza e doença ${ }^{41}$. Outro exemplo: comentando Jo 6, 19 onde se diz que o barco dos apóstolos teria avançado 25 a trinta estádios, Agostinho pergunta o que seria 25, e responde: cinco são os livros de Moisés e, portanto, o quadrado de cinco seria a perfeição da Lei. Mas a Lei era imperfeita antes da vinda de Cristo; quando Cristo entrou na barca trouxe outro

\footnotetext{
${ }^{37}$ Evangelho de João 122, 8, NPNF 7, 442 b.

${ }^{38}$ Evangelho de João, 122, 8, NPNF 442b / 443 a.

${ }^{39}$ Sermões sobre as lições NT 64, item 3, NPNF 6, 453.

${ }^{40}$ Sermões sobre as lições do NT 1, 31-35, NPNF 6, 257-259.

${ }^{41}$ Evangelho de João 17, 5-6, NPNF 7, 112-113.
} 
número: o 6 da criação do mundo, e então com 6 x 5 chega-se à perfeição da Lei em Jesus Cristo $^{42}$.

Aliás, o número 6 tem uma atração especial para Agostinho, que chega a dizer: é mais fácil passarem o céu e a terra do que fazer com que o número seis não seja perfeito ${ }^{43}$.

Ao discutir sobre o que se conhece, e o que se pode dizer quando não se sabe muito, Agostinho confessa que conhece pouco de geometria, mas sabe pelo menos o que é uma esfera e uma linha. Começa então a explicar o que é uma linha, e o que é uma esfera, e como podem, e como não podem ser cortadas; depois de algumas ambiguidades, ele concorda em que, de questões básicas de Geometria sabe o suficiente para não ter do que duvidar $^{44}$. Mas, um pouco mais adiante ${ }^{45}$ reconhece, ao tratar do círculo, que há coisas, como a quantidade de raios do círculo, que se podem entender pela razão, mas não pela imaginação.

\section{II}

\section{Elementos do universo}

\section{O Firmamento/O Céu}

O firmamento, ou céu visível, está estendido sobre nós como uma pele, diz Agostinho; mas adverte: esta é também uma noção alegórica, porque o firmamento que nos cabe é a Palavra de Deus ${ }^{46}$. É olhando para o firmamento que as pessoas sentem confiança, porque as nuvens passam, mas o firmamento, isto é, a Palavra Divina permanece constante ${ }^{47}$; idêntica concepção aparece ${ }^{48}$ quando os santos são comparáveis às estrelas no firmamento.

Embora com algumas ressalvas e dúvidas Agostinho inclina-se a afirmar que a abóbada celeste, o céu, que alguns dizem que é como uma pele estendida, é esférico: refere-se, nesta passagem, ao que disse nas Confissões ${ }^{49}$ acerca da semelhança com a pele: “se não é esfera é abóbada (...) mas se é esfera é abóbada por todas as partes"50.

${ }^{42}$ Evangelho de João 25, 6, NPNF 7, 162.

${ }^{43}$ Com. Genesis 4, 7, 13, p. 127.

${ }^{44}$ Solilóquios 1, 4, 9-10, Paulus 25-27. NPNF 7, 540.

${ }^{45} \mathrm{Ib} .2,20,34$ ss.

${ }^{46}$ Confissões, 13, 15, 16.

${ }^{47}$ Confissões 13, 15, 18.

${ }^{48}$ Confissões 13, 34.

${ }^{49} \mathrm{Ib} .13,15$.

${ }^{50}$ Com. Genesis 2, 9, 21-22, p. 64-65. 
“Observa o céu: em toda a parte e em todos os lugares o céu cobre a terra, nem há nenhuma parte da terra que não esteja coberta pelo céu". Do céu nos vem a chuva, para que a terra dê frutos, a luz, o ar para respirar. Sem a ajuda do céu a terra sucumbirá ${ }^{51}$. Em algumas passagens a ideia de céu está tão distante da de céu/firmamento que consiste apenas numa alegoria sobre a vida espiritual, sem referência ao cosmo material.

Mas o que é o "céu do céu"? ${ }^{52}$ : esse nós não vemos. O céu do céu está além, é misterioso, e comparado com ele o céu/firmamento que nós vemos forma um conjunto com a terra, ou seja, é material.

\section{Os corpos celestes/os astros/astronomia/astrologia}

O firmamento (céu) não é vazio, o espaço não é vazio. A simples observação noturna nos faz ver que o espaço cósmico é pontilhado de luzes, que identificamos como corpos celestes. Agostinho parte desta constatação para explicar algo mais sobre o que objetivamente são esses corpos: "Há estrelas e luzeiros no céu que servem de sinais, indicam as estações, as horas e os anos. Com certeza existem". Esses corpos celestes são sinais, diz ele, sinais com os quais marcamos as estações e definimos o começo e fim de cada ano, e dividimos as horas ${ }^{53}$, mas, adverte ele, nem por isso o movimento desses corpos se identifica com o tempo. O que é que há para investigar acerca dos astros: o número das estrelas, a medida das regiões siderais, e o curso dos astros, e ainda a previsão dos eclipses do sol e da lua, calculando a hora e o lugar dos eventos, isto é, qual a parte da respectiva luz se vai ocultar em cada eclipse; e também determinar o dia e a hora dos solstícios e equinócios. Tudo isso, diz ainda, eu sabia, porque "por cálculos matemáticos e pelos próprios olhos averiguara" ${ }^{54}$. Porém o importante, continua ele, não é saber tudo isso, mas, sem se orgulhar da ciência, com humildade buscar "piedosamente a Verdade, o Artífice da criação.” Recomendação que repetirá em outras passagens. Por exemplo: mais adiante, em modo de conclusão, desenvolve uma alegoria em que os dons que Deus dá aos homens são comparados às estrelas do céu ${ }^{55}$. E prossegue: estamos sujeitos, na Terra, às constelações, aos dias e aos anos, mas “deles nos elevamos até Deus por meio de uma contemplação inefável" e assim alcançamos o discernimento do que é espiritual.

\footnotetext{
${ }^{51}$ Ex. Salmos 103, 15, NPNF 8, 508 .

${ }^{52}$ Salmo 113, 16, Confissões 12,2.

${ }^{53}$ Confissões 11, 23.

${ }^{54}$ Confissões, 5,3.

${ }^{55}$ Confissões 13, 18.
} 
As estrelas estão no céu muito antes da existência do homem: os nomes das estrelas são nomes de homens, mas as estrelas existem desde muito antes desses homens - é que, quando quiseram honrar certas pessoas deram seus nomes às estrelas ${ }^{56}$. Agostinho estava bem informado acerca das teorias sobre as estrelas: contra a opinião simplória que imagina as estrelas fixas no firmamento, todas num mesmo plano, ele sabe que os diferentes tamanhos e brilhos delas se devem a que estão a diferentes distâncias da Terra, têm tamanhos muito desiguais - e algumas delas são maiores do que o Sol.

Mas por que razões se observam os astros? Os astrônomos dividem as regiões do céu para nelas ordenar as constelações, e os camponeses e marinheiros as observam para prever o clima; ou ainda também o fazem os que atravessam o deserto - tudo isso muito diferente das alucinações dos astrólogos que querem prever o futuro ${ }^{57}$. Semelhante referência a essa previsão de camponeses e marinheiros está no Comentário ao Genesi ${ }^{58}$ porque "horas, dias e anos determinados como nós os conhecemos não seriam feitos senão pelo movimento dos astros" e continua explicando o movimento do Sol, o ano de 365 dias, e as 6 horas que se lhe devem acrescentar, e que vão compor o ano bissexto, e outros cálculos que formam os circuitos dos luzeiros como indicadores da medição do tempo ${ }^{59}$.

Embora considere que a adivinhação, ou a predição das coisas futuras, feitas pelos astrólogos, sejam ímpias e absurdas, Agostinho reconhece que há pessoas bem instruídas que relacionam a posição das constelações com o comportamento dos animais; mas são loucuras ridículas e vazias, na sua opinião ${ }^{60}$. Em outros lugares Agostinho critica a astrologia e considera falsas e vãs as suas predições ${ }^{61}$. Ele refuta terminantemente tanto a astrologia como os horóscopos ${ }^{62}$. Em nenhum momento concede aos astrólogos algum tipo de aceitação ou de reconhecimento: tudo neles é falso e contra Deus. No comentário ao Evangelho de João é inflexível: quem procura o astrólogo comete pecado; e para que não fiquem dúvidas acrescenta: queimamos os livros deles ${ }^{63}$.

Considera o determinismo astrológico imbecil e insensato ${ }^{64}$ e ainda frívolo, coisa de "absurdas historinhas" e para finalizar: enigmas dos demônios ${ }^{65}$.

\footnotetext{
${ }^{56}$ Ex. Salmos 94, 2-3, NPNF 8, 460.

${ }^{57}$ Carta 55, viii, 14-15, NPNF, p. 308.

${ }^{58}$ Com. Genesis 2, 14, 29, p. 73.

${ }^{59} \mathrm{Ib}$.

${ }^{60}$ Confissões 7, 6, NPNF 1, 105.

${ }^{61}$ Cidade de Deus, 5, 1-8, Gulbenkian 461-484, NPNF 2, 84-89.

${ }^{62}$ Doutrina Cristã 2, 23-24, Paulinas 126-127, NPNF 2, 21-22 e 2, 545-546.

${ }^{63}$ Evangelho de João 8,8 e 10,5, NPNF 7, 60 b e 70 b.

${ }^{64}$ Com. Genesis 2, 17, 36, p. 79.

${ }^{65} \mathrm{Ib} .37$, p. 80.
} 
Porque Agostinho reagia com tanta vivacidade e má vontade quando se tratava de astrologia? Por várias razões, mas destaquemos duas: o astrólogo quer substituir-se à vontade divina descobrindo a vontade dos astros - e a vontade dos astros substitui a previsão divina (presciência); e porque é uma prática fortemente arraigada nas doutrinas pagãs, aceitá-las seria uma intromissão pagã no cristianismo.

"Aqueles que acreditam em destino afirmam que não só as ações e os acontecimentos, mas, mais ainda, as nossas próprias vontades dependem da posição das estrelas no momento da concepção e do nascimento, posições a que eles chamam constelações." Porém não são as estrelas, mas a vontade de Deus e a sua graça que influem nas nossas vidas $^{66}$.

A propósito da astrologia vale a pena citar outra questão de "falsa ciência" que irritava Agostinho: o boato de que Jesus teria escrito livros de magia em que explicava como fazia seus milagres. Agostinho considera essa suposição uma audácia ilusória e ridícula ${ }^{67}$.

Já a astronomia lhe merece respeito, pois ela não pretende prever o futuro, mas demonstrar o curso dos astros, seu despontar e declinar, e seus movimentos. Porém, diz ele, a astronomia é de pouca utilidade para o conhecimento das Escrituras, e, pela sua proximidade com a astrologia, há que ter precauções e não a apreciar demais ${ }^{68}$.

Num dos escritos para rebater as doutrinas de Pelágio diz Agostinho que parece, ao adversário, que há questões que se supõe que não dizem respeito à fé; mas Pelágio está enganado, porque algumas dessas questões se referem à vida dos profetas e dos apóstolos, enquanto outras tratam de "quantos céus existem (...) se os elementos do mundo visível são quatro ou mais, quais são as causas dos eclipses do sol ou da lua, que os astrônomos têm o costume de prever em certas estações (...)" e muitas outras, e todos percebemos que a nossa ignorância a esse respeito é compatível com uma fé cristã sólida, e que, por outro lado, uma opinião errada sobre esses assuntos não implica em nenhuma heresia ${ }^{69}$.

Agostinho sabe como é o Sol, e como acontece um eclipse: não é por algum tipo de milagre, devido ao poder de um ser superior que altera o curso dos astros, mas, pelo contrário, e algo que se dá no curso do sol regulado por leis inalteráveis ${ }^{70}$. Ele sabe também que "um eclipse regular do Sol só se produz na lua nova".

${ }^{66}$ Contra duas cartas dos pelagianos NPNF 5, 13, 96.

${ }^{67}$ A Harmonia dos Evangelhos 1, 9-11, item 14-17, NPNF 6, 83-84.

${ }^{68} D C 2,22$ (32) e 30 (46), NPNF 2, 21 (32) e 29 (46).

${ }^{69}$ Sobre o pecado original, 2, 27, NPNF 5, 246.

${ }^{70}$ Cidade de Deus 3, 15, Gulbenkian, p. 321, NPNF 2, 51. 
Sobre a Lua corrige a opinião daqueles que supõem que a Lua possa ter sido criada incompleta: ela foi criada cheia, e permanece sempre cheia, ou inteira: "A Lua tem um corpo inteiro, brilha perfeita em toda a sua rotundidade, mesmo com sua luz em forma de chifre (...) o que se modifica não é o próprio luzeiro mas o que a ilumina" (o modo como o Sol a ilumina) e prossegue explicando as fases da $\mathrm{Lua}^{71}$.

Agostinho levanta também a questão de saber se os astros são animados, ou seres inteligentes, racionais, como supunham muitos, inclusive cristãos; ele não quer se envolver em opiniões, diz que pode ser correto, que as Escrituras não o negam, mas que ele prefere não discutir o assunto ${ }^{72}$.

\section{A luz}

O primeiro sentido em que Agostinho apresenta a luz é o espiritual: o Senhor é a luz que me tira das trevas da ignorância ${ }^{73}$. Mas aqui aparece outra alegoria tirada do mundo material, que é a oposição entre a luz e as trevas. A luz espiritual, divina, é a luz que não muda, luz que nos leva à verdade e à eternidade ${ }^{74}$. Essa luz, que ilumina o coração, é como que uma extensão espiritual da luz corporal, pela qual recebemos os prazeres das formas e das $\operatorname{coisas}^{75}$. A luz é tomada no seu sentido alegórico e espiritual quando Agostinho afirma que sem luz até "o céu dos céus" seria escuro (um abismo de trevas), mas é luz do Senhor; e quando esclarecidos pela luz divina os homens recebem vestes tecidas da luz divina ${ }^{76}$.

Na obra da criação do mundo existiam as trevas, e depois a luz, e, para Agostinho, o sentido alegórico é explícito: a luz é "a sociedade santa dos anjos aos quais o brilho da verdade dá um esplendor inteligível, e as trevas contrárias, isto é, os sombrios espíritos dos maus anjos desviados da luz da justiça" 77 . Acostumados como estamos a este tipo de associação de ideias, que vem da Escritura, não nos damos conta de como ela reflete a observação do mundo material: a luz pelo seu brilho nos permite ver as coisas do mundo como elas são, o que, reportado ao mundo mental, se traduz por um esplendor da inteligência, que dá à mente maior compreensão. Neste aspecto, além de sua forma

\footnotetext{
${ }^{71}$ Com. Genesis 2, 15, 30-31, p. 74-75.

${ }^{72}$ Com. Genesis 2, 18, 38, p. 81.

${ }^{73}$ Confissões 4, 15, 25.

${ }^{74}$ Confissões 7, 10, 16.

${ }^{75}$ Confissões 10, 34, 50-51.

${ }^{76}$ Confissões 13, 8.

${ }^{77}$ Cidade de Deus 11, 19, Gulbenkian 1033, NPNF 2, 215.
} 
espiritualista e metafórica de entender o mundo, Agostinho é realista, toma o mundo como ele se oferece pelos sentidos.

A luz é um dos elementos que mais se prestam à alegoria, e a transpor o sentido do material para o espiritual. Os olhos humanos precisam de luz, é nela que os olhos se refrescam; na escuridão os olhos enfraquecem, pois é da luz que se alimentam; se a escuridão se prolonga os olhos desfalecem. Mas a luz que alimenta tantos olhos não diminui. Sem dúvida as concepções de Agostinho a respeito da luz são bem de senso comum, pois o que lhe interessa é a outra luz: a luz do espírito, da qual a fonte é Deus, Ele que é tudo para nós ${ }^{78}$. De fato, Agostinho insiste em que existe uma luz superior: "Ela é a inefável e incompreensível luz das mentes". E prossegue: é preciso deixar que a luz comum do dia nos ensine, tanto quanto puder, o que é a luz superior. Assim vamos por etapas vendo com os olhos cada vez mais luz: o fogo, as estrelas, a lua, a brilhante aurora, e depois o céu luminoso. Assim os mestres nos ensinam a gradualmente passar das luzes materiais para a iluminação espiritual ${ }^{79}$.

\section{A Terra}

Agostinho não diz que a Terra é plana, mas por vezes afirma que ela é redonda: “(...) embora se creia que o mundo tem uma forma esférica e redonda, e embora haja algum argumento para demonstrar isso" 80 . Já a tradução em inglês diz mais peremptoriamente: "mesmo que se suponha, ou esteja cientificamente demonstrado que o mundo é redondo e de forma esférica - although it is supposed or scientifically demonstrated that the world is of a round and spherical form (...)" ${ }^{" 1}$. Seja qual for a tradução não há dúvida de que Agostinho afirma como certo que a Terra é redonda, e o restante da argumentação deste capítulo só faz sentido se essa for a opinião dele.

Agostinho sugere, mas deixa lugar a dúvidas, que o planeta Terra é redondo, pois ao falar do livro dos Salmos diz: costumamos dizer diariamente: "o globo da Terra", e "o globo das terras" e de outras coisas temos expressões usuais ${ }^{82}$.

De fato, Agostinho está a discutir a possibilidade da existência de antípodas - que, segundo ele, nunca ninguém viu, nem a sua existência parece provável. A Terra, diz ele,

\footnotetext{
${ }^{78}$ Evangelho de João 13, 5, NPNF 7, 88 b.

${ }^{79}$ Solilóquios 1, 23, NPNF 7, 545, Paulus 45.

${ }^{80}$ Cidade de Deus 16, 9, Gulbenkian 1477.

${ }^{81}$ NPNF 2, 315.

${ }^{82}$ Sobre os Salmos 150,2, NPNF 8, 682.
} 
está suspensa no espaço - "no interior da abóbada do céu" de tal modo que não tem nem "em baixo" nem "em cima". Se houver habitantes em toda ela, os que estiverem no lado oposto ao nosso considerariam que nós estamos em baixo e eles em cima; eles estariam no lado em que o sol nasce quando para nós se põe. Esta argumentação de Agostinho, repetimos, só faz sentido na hipótese de a Terra ser redonda. Mas ele apresenta dificuldades à "possibilidade de povoamento do lado oposto ao nosso: pode ser que "o outro lado" seja todo constituído por água; seria também “demasiado inverossímil terem alguns homens navegado todo o Oceano para chegar ao outro lado da terra".

Por falar em oceano vale a pena chamar a atenção para o fato de Agostinho pouco falar da água, quer na sua materialidade, quer como símbolo. Geralmente a água é citada ou a propósito da Criação, ou na sua relação com a Terra: inclusive ele mostra que no relato dos seis dias da Criação há uma certa confusão entre a terra e a água - desta não se diz que foi criada, como se estivesse incluída na menção à Terra (globo terrestre ${ }^{83}$ ).

Agostinho não desconhece, nem esquece, que a água pode se apresentar em várias condições (estados), entre os quais o vapor - e neste ponto é muito clara a sua explicação das nuvens: "As nuvens adquirem tal forma mediante a reunião e ajuntamento de pequenas gotas, as quais, se se condensam a ponto de muitas pequenas gotas se reunirem em uma grande, de modo que o ar não as sustente, caem para o solo por seu peso, constituindo assim a chuva" 84 .

Noutra passagem explica de outra maneira o ciclo da água:

Com o movimento do ar levanta-se do mar de um modo invisível um vapor de água doce, ou seja, com estas evaporações que não nos é possível perceber, formam-se as nuvens. Assim, umedecida a terra pelas chuvas, a água se infiltra para as cavernas escondidas, e depois transpirando tanta água quanto tem reunida, a deixa passar por diversos condutos brotando em fontes pequenas ou grandes, aptas para formar $\operatorname{rios}^{85}$.

Existe algum lugar em baixo da Terra para onde vão os que amam as coisas terrestres, e se comportam no pecado. "Eles não queriam perder a Terra quando crucificaram Cristo, mas foram para os lugares mais profundos da Terra. E o que são os lugares mais baixos da Terra? Os da luxúria. Mais vale caminhar sobre a Terra do que por causa da luxúria ficar debaixo da terra" $"$.

${ }^{83}$ Com. Genesis 1, 13, 27, p. 35/36.

${ }^{84}$ Com. Genesis 2, 4, 7, p. 55.

${ }^{85}$ Comentário literal ao Genesis inacabado 14, 47, p. 631.

${ }^{86}$ Exp. Salmos, 63, 14, NPNF 8, 262 b. 


\section{A matéria}

A matéria não é coeterna com o Criador, como supõem muitos filósofos, e a maior parte das cosmogonias. Nestas é frequente se descrever a criação como um ordenamento do caos, ou da matéria informe. Mas, pensa Agostinho, se o caos fosse alguma coisa, ou uma matéria indeterminada, ela seria um princípio rival de Deus, e Deus não seria o Ser Supremo e absoluto.

A matéria primordial, por meio da qual Deus fez todas as coisas físicas, era matéria informe, absolutamente despojada de qualquer concretização ${ }^{87}$. Essa matéria era informe, e precisamos de abstrair da imaginação para poder concebê-la em sua potencial qualidade. Além disso tal matéria não é o caos anterior à Criação, como muitas cosmogonias pressupõem: uma massa preexistente ao ato criador dos deuses - a propósito lembremos que a Bíblia hebraica diz textualmente: Bereshit barah Elohim: no princípio os deuses etc. o que mostra como o relato do Genesis é dependente dessas cosmogonias mesopotâmicas, e o conceito da unicidade de Yahweh ainda era confuso. Mas Agostinho considera que a matéria primordial foi criada por Deus: se Deus se tivesse servido de algo preexistente para criar o mundo haveria dois criadores (como no Avesta de Zoroastro). Mas Agostinho se depara com uma dificuldade para definir o que é a matéria, e responde: "um certo nada que é e não é" 88 . Esse nada de algum modo existe "invisível e informe", como um abismo sem luz, como um "quase nada" capaz de vir a ter forma ${ }^{89}$.

Sobre a constituição física da matéria atual, aquela que podemos perceber pelos sentidos, Agostinho mostra conhecer as noções mais gerais, isto é, as que se referem aos átomos como partículas mínimas:

Pois os mesmos estudiosos comprovam, mediante argumentos sublimíssimos, que não há nenhum pequeno corpúsculo no qual haja limites para a divisão, mas que tudo pode ser dividido infinitamente, visto que toda a parte de um corpo é corpo, e é necessário que todo corpo tenha a metade da sua quantidade $^{90}$.

"O material que os antigos chamavam hule, matéria, também não pode ser chamado de mau(..). Por hyle eu quero dizer um certo material absolutamente sem forma nem qualidade (...) como aquilo do qual alguma coisa pode ser feita (...) mas que só pode ser pensada por meio de uma certa privação de aparência." 91 .

\footnotetext{
${ }^{87}$ Confissões 11, 4-9, NPNF 11, 6 ss.

${ }^{88}$ Confissões $11,6$.

${ }^{89}$ Confissões 11, 8.

${ }^{90}$ Com. Genesis 2, 4, 8, p. 55.

${ }^{91}$ A Natureza do Bem, 18.
} 
É conveniente fazermos aqui a distinção com relação à noção de substância: "Aquilo pelo qual os seres são o que são, e dela são formados, inclusive o próprio Deus" ${ }^{92}$. As substâncias sempre são boas (ou do bem) tanto as incorruptíveis como as corruptíveis por isso o mal não tem substância ${ }^{93}$.

\section{O fogo}

Agostinho presta atenção ao fogo material, mas só de passagem, quando observa as propriedades do fogo: "ele é brilhante mas enegrece o que queima (...) é belo de cor (...) mas descora quase tudo o que o envolve e toca". O fogo faz a matéria que está queimando se tornar negra, mas se tocar nas pedras elas ficam mais brancas. "Deste modo, quando arde na madeira para cozer as pedras, o fogo produz efeitos contrários em coisas não contrárias" $" 94$. A madeira enterrada apodrece, mas se o fogo a transformou em carvão pode ser enterrada e não apodrece.

Porém, segundo o seu hábito, Agostinho considera que o fogo material é símbolo e alegoria de muitos tipos de fogo. Há o fogo eterno, que queima os condenados sem se consumir nem se apagar ${ }^{95}$, o fogo da fé que salva o pecador ${ }^{96}$, o fogo das tribulações e dos amores terrenos ${ }^{97}$ mas esse mesmo fogo pode salvar, e o fogo que põe à prova os que serão salvos - mas a outros a prova do fogo vai condenar. De fato, umas almas são como o ouro, que se purifica pelo fogo, e outras são como palha e madeira, que se consomem. Mais uma vez Agostinho mostra seus dotes de observador das coisas materiais e comuns, que explica com clareza ${ }^{98}$. Às vezes num curto parágrafo vários sentidos de fogo se sobrepõem: o fogo do céu, que é a firmeza dos santos, mas que ao atingir os ímpios se torna em raiva ardente que atormenta, e matará o anticristo, perseguidor da Igreja - mas esse ainda não será o fogo do Juízo Final ${ }^{99}$.

As mesmas imagens e alegorias do fogo se repetem em diversos textos de Agostinho: fogo que purifica, fogo que castiga, fogo que salva ${ }^{100}$.

\footnotetext{
${ }^{92}$ Confissões 7, 2 e 4.

${ }^{93}$ Confissões 7, 12.

${ }^{94}$ Cidade de Deus 21, 4, Gulbenkian 2134, NPNF 2, 454.

${ }^{95}$ Cidade de Deus 21, 26 etc.

${ }^{96} \mathrm{Ib}$.

$97 \mathrm{Ib}$.

${ }^{98}$ NPNF 473

${ }^{99}$ Cidade de Deus 20, 12, Gulbenkian 2029, NPNF 432.

${ }^{100}$ Exp. Salmos 66, 15, NPNF 8, 278 b.
} 


\section{O tempo}

O tempo é uma constante preocupação e tema de interesse para Agostinho, que parece incomodado por não ser capaz de entender nem explicar o que é o tempo. O ponto de partida para suas tentativas de explicação está, é claro, na Criação, pois se de algo não se pode duvidar é que Deus vive na eternidade, fora do tempo, e antes da Criação não havia tempo - a rigor nem se pode dizer "antes". O mundo foi feito, não no tempo, mas "com o tempo", pois ao criar o mundo Deus criou nele o movimento sucessivo $^{101}$. Mas deste ponto de partida claro e de certo modo simples, seguem-se perguntas difíceis.

O conceito judaico-cristão de tempo é peculiar, distinto de outras culturas em que o temo é cíclico; mas para o cristão o tempo do universo é retilíneo, nele não existem ciclos, nem retorno, ou repetição ${ }^{102}$. Pode então o tempo identificar-se com o movimento dos astros? Não, o tempo não existe por causa do movimento, mas é algo que existe como algo por si mesmo: ainda que não houvesse coisas materiais, que não houvesse astros, o tempo existiria - mas como seria medido?

Há nas Confissões ${ }^{103}$ uma primeira constatação, que é fruto de o tempo ser algo percebido pela mente (pela alma) como uma duração por antes e depois. Sem percepção não há tempo, porque o tempo é tempo percebido. Mas Agostinho se preocupa com a outra possibilidade, a de o tempo ser algo que exista fora da mente, de modo objetivo, e nesse caso seria algo relacionado à matéria, e portanto extenso; isso só será verificável se o tempo poder ser medido ${ }^{104}$. Essa possibilidade é real, mas ainda com conotações antropológicas, pois o exemplo dado é o da linguagem - sílabas breves e longas - algo que ele estuda detidamente no tratado da música. Outra possibilidade de medida seria pelo movimento do sol ${ }^{105}$ e dos outros astros, mas esse argumento não é decisivo, porque Agostinho supõe - como hipótese inverificável, mas que ele dá como certa - que, mesmo que os astros parassem o tempo não deixaria de existir ${ }^{106}$. Mas insiste ${ }^{107}$ : o tempo medido é duração, ou é movimento dos astros? Contudo aqui entra outra componente, que é a

\footnotetext{
${ }^{101}$ Cidade de Deus XI 6 Gulbenkian 1001.

102 Cidade de Deus XII 20 e 21 Gulbenkian 1131-1137.

${ }^{103}$ XI-XII.

104 XI 16-21.

105 XI 18.

106 XI 23.

${ }^{107} \mathrm{Ib}$.
} 
velocidade $^{108}$, e também o tempo parado, isto é, sem movimento; e conclui: "portanto o tempo não é o movimento dos corpos" ${ }^{109}$; consequentemente, lamenta Agostinho, "ainda ignoro o que seja o tempo" ${ }^{110}$. Persiste na mesma questão da medida que seria (não o diz assim) uma prova da objetividade do tempo; explica um pouco melhor o exemplo gramatical das sílabas longas e breves, e uma vez que o som é algo material (supomos que pensou assim, mas não o diz) temos aí um princípio de extensão, pois só o que é material é extenso - chama-lhe, porém, distensão. Retoma, porém, o antropocentrismo, e diz que essa distensão não é do tempo, mas da alma ${ }^{111}$, o que o leva outra vez a perguntar: afinal medimos o que, ao medir o tempo ${ }^{112}$. Ao chegar a este ponto Agostinho parece que se cansou, e desistiu de achar a realidade do tempo, porque afinal não saiu do mesmo lugar, não progrediu, pois o que se mede ao medir o tempo é a impressão ou percepção do tempo pelo espírito ${ }^{113}$; e, depois de mais algumas considerações, em que reduz o passado à memória, e o futuro à expectativa - sem sair, pois, do antropocentrismo termina com uma oração e invocação ao "Senhor dos profundos segredos" o Criador que só Ele sabe o que é o tempo ${ }^{114}$.

Já que Agostinho "desistiu" vamos tentar avançar na sua concepção do tempo procurando-a em outras obras suas, e não só o tempo, mas seu contexto geral, isto é, a ordem do mundo e o espaço.

Tudo o que já existiu, ou sabemos que vai existir, existe em nós pela memória. O que existiu só tem realidade como presente recordado - ou antecipado ${ }^{115}$. As revoluções (evoluções circulares cíclicas) dos astros só por si não são a medida do tempo, pois tal como na roda do oleiro há mais devagar e mais rápido, mas nem por isso deixa de haver tempo, enquanto a roda, ou os astros rodam seus círculos. Agostinho continua mantendo a ideia fundamental de que o tempo é o tempo vivido; mas nem por isso desiste de saber o que é que está "por trás" dessa ideia: o que eu quero saber, diz Agostinho, "é o poder e a natureza do tempo, pelo qual nós medimos os movimentos dos corpos, e poder dizer, por exemplo, que tal movimento é o dobro de outro"116. O dia é o tempo que o sol se demora sobre a terra, e também a rodada dele do Oriente ao Ocidente. Mas não sabemos

\footnotetext{
${ }^{108}$ XI 24.

109 XI 24.

${ }^{110}$ XI 25.

111 XI 26.

112 XI 27.

113 XI 27.

114 XI 31.

115 Confissões 18, 23, p. 169.

116 XI 23, 30 .
} 
ao certo se o que constitui o dia é o movimento do sol, ou a sua duração, ou as duas coisas juntas.

Neste ponto Agostinho se serve de um relato mitológico (alegórico) da Bíblia para reforçar a sua pergunta (de caráter metafísico); quando Josué rezou e pediu a Yahweh que o sol parasse para que ele pudesse concluir a batalha e exterminar os inimigos ${ }^{117}$ é certo que o sol parou, mas o tempo não. Portanto o tempo não se identifica com o movimento do sol - este é apenas a medida do dia, não do tempo. Entretanto, Agostinho tinha refletido, e diz que o tempo é uma extensão (ou distensão). Mas é uma distensão de que? Se o tempo não é o movimento dos corpos, parece que se pode dizer que é medido pelo movimento, mas não é o movimento ${ }^{118}$. Portanto a medida da extensão, ou distensão do tempo mede o tempo, ou mede a alma que o percebe? Ele está tão perplexo e de certo modo confuso a este respeito que noutra passagem se contradiz: "o tempo é o movimento da criatura de um lugar para outro com a sucessão das coisas" mas, como que para se justificar, acrescenta: "conforme a ordenação de Deus"119.

“O tempo não descansa, nem rola ociosamente pelos sentidos, pois produz na alma efeitos admiráveis ${ }^{120}$. "O tempo vinha e passava, dia após dia. Vindo e passando inspirava-me novas esperanças". O tempo, objetivamente falando, é um contínuo uniforme, com velocidade sustentada e sem pausas; mas não é nada em si mesmo, é apenas a passagem dos eventos e sensações. Só existe por referência à alma. Tempo é tempo vivido.

Os tempos nunca param, nunca são os mesmos, um tempo longo só é longo porque acontecem muitas coisas: por isso no tempo não há tempo que seja completamente presente, ao passo que na eternidade o todo está sempre presente, e nada passa; é nessa condição que nós vivemos e não temos poder para parar o tempo, nem para entendê-lo"

O passado já não existe, o futuro ainda não existe. O que existe é só presente e sempre mudando, porque o presente é das coisas que atualmente existem, e das mentes que atualmente o percebem. Portanto existe como subjetividade, não como algo em si existente $^{122}$. De algum modo pode-se medir o tempo, por mais longo e mais curto, mas sempre por referência subjetiva ao "sentir o tempo passar"123.

\footnotetext{
117 Js 10, 12-14.

${ }^{118}$ Confissões 11, 24, Vozes, p. 288-289.

119 Com. Genesis 5, 5, 12, p. 176.

120 Confissões 8, 13.

${ }^{121}$ Confissões 11, 11.

122 Confissões 11, 15.

${ }^{123}$ Confissões $11,16$.
} 
Porém a contradição persiste ${ }^{124}$ : como é que se pode medir algo que não existe? Porque: se passado e futuro não existem, e o presente está sempre deixando de ser, o que se quer medir é um contínuo deixar de existir. E a pergunta permanece: medimos algo que não sabemos o que é. Porque o passado é uma memória que está na alma, e o futuro uma expectativa que também está na alma. Voltamos, portanto, ao início: o tempo é uma distensão da alma e não sabemos o que é fora da alma. Enfim, Agostinho não consegue sair de duas aporias: que o tempo é tempo vivido como distensão da alma, e que isso ainda não diz o que é o tempo; porque o que o tempo seja, objetivamente, em si mesmo, não se consegue saber. Cada vez que parece que obteve uma definição Agostinho verifica que ela é ou vazia, ou contraditória, ou inadequada.

Ele fica incomodado por não ser capaz de explicar o que é o tempo, e volta ao problema em diversos escritos. Por exemplo: ao discutir o que é coeterno, e se pode haver uma criatura coeterna com Deus, elabora uma longa dissertação. Coeterno, diz, não é o mesmo que coevo; este se diz daqueles "que têm a mesma medida no tempo"125. "Aqueles que chamamos coevos começaram a existir ao mesmo tempo". Ao menos aqui Agostinho descansa em algo que parecia correto, mas que não o ajudou a saber o que é o tempo.

\section{A natureza, a física dos corpos e as razões seminais}

"Toda a natureza do próprio universo que nos rodeia, e à qual nós mesmos pertencemos, proclama que tem um excelente Criador, que nos deu a mente e a razão natural" $" 126$.

O que devemos saber acerca da natureza? Nada mais além de que a causa de todas as coisas é a bondade do Criador. Para a fé do cristão não é necessário saber, como os antigos filósofos, "a força e o número dos elementos; o movimento e a ordem dos corpos celestes, e também os seus eclipses, e a forma dos céus; as espécies e as naturezas dos animais, das plantas, pedras e fontes, dos rios e das montanhas; acerca das cronologias e das distâncias, e dos sinais que anunciam tempestades (...)" porque nem esses filósofos sabiam tudo, nem ao cristão essas coisas fazem falta ${ }^{127}$. Mais adiante ${ }^{128}$ continua: não é essencial para a felicidade do homem saber as causas dos terremotos e maremotos, basta saber discernir

\footnotetext{
124 Confissões 11, 27.

125 Sermões sobre as lições do Novo Testamento 67, (117), NPNF 6, 461.

${ }^{126}$ Trindade 15, 14, 6, NPNF 3, 202.

${ }^{127}$ Enquiridion 9, NPNF 3, 239/240.

${ }^{128}$ Ib. 16, p. 242.
} 
entre o bem e o mal. Em toda a sua obra Agostinho utiliza as ciências da matéria, mas há nisso certa oscilação, já que em diversas passagens ele insiste na inutilidade das ciências:

Estas coisas, diz ele, são "de nenhum proveito para a salvação" ${ }^{129}$; e pouco depois: "Não é vantagem nem convém investigar com sutilezas as distâncias e grandezas dos astros, e sim empregar o tempo necessário a esta investigação em coisas mais sérias e melhores"130.

O que acontece na natureza é maravilhoso, mas estamos tão acostumados a ver que não nos admiramos mais com a sucessão dos dias e das noites, com a ordem estabelecida nos céus, com a evolução dos anos divididos em quatro partes, as folhas das árvores que caem e se renovam, o poder ilimitado das sementes, a beleza da lua, a variedade das cores, dos sons, dos sabores e odores ${ }^{131}$.

Por estranho que pareça é numa das passagens mais místicas e mais citadas das Confissões - "amor meus, pondus meus" - que Agostinho expõe a mais explícita e literal explicação do mundo material. Segundo a Física tradicional (que durou até à neoescolástica do século XX) "o corpo, devido ao peso, tende para o lugar que lhe é próprio, porque o peso não tende só para baixo, mas também para o lugar que lhe é próprio"; Agostinho prossegue citando vários exemplos: o fogo que sobe, a pedra que cai, o azeite que sobrenada na água, a água que submerge sob o azeite, e vai comentando: "Movem-se segundo o seu peso. Dirigem-se para o lugar que lhes compete. As coisas que não estão no próprio lugar, agitam-se, mas, quando o encontram, ordenam-se e repousam". Só então Agostinho entra com o tema que quer expor: "O meu amor é o meu peso (...) é ele que me leva". Somos arrebatados, ardemos, partimos, cantamos, isto é, como ele tinha acabado de dizer: nos agitamos até que chegamos onde é o nosso lugar, e ali desejamos permanecer ${ }^{132}$. O que lemos neste trecho, mais do que em outros em que a questão é apenas sugerida, ou subentendida, é que na interpretação espiritual e alegórica dos diversos elementos e setores do cosmo Agostinho - preferencialmente, mas nem sempre - só se eleva à virada que transcende o físico e alcança o reino da alma e da vivência com Deus depois que firmou bem o sentido literal e físico das observações das coisas materiais. E essas coisas, como todo o cosmo em sua materialidade, são dignas e boas porque servem, e se projetam - ou a alma se projeta através delas - para o mundo

\footnotetext{
${ }^{129}$ Com. Genesis 2, 9, 20, p. 64.

${ }^{130}$ Com. Genesis 2, 16, 34, p. 78.

131 A utilidade da fé 34.

${ }^{132}$ Confissões $13,9$.
} 
espiritual e divino. E já que estamos falando de corpos físicos, o que é, para Agostinho, um corpo material?” Responde: “Qualquer natureza que ocupa espaço local pelo comprimento, largura e altura"133. Mais objetivo impossível.

A matéria corporal, que constitui os corpos do universo, embora bruta tem em si potenciais de evolução. Esses potenciais são as razões seminais, os princípios racionais da vida, que Deus criou para dar continuidade à sua obra; mas esses princípios não agem por si sós: o que eles fazem é feito com o concurso divino.

Agostinho aceita este conceito estoico e não o desenvolve, apenas o retoma brevemente em muitas passagens. Contudo ao falar da criação nota-se a tendência a considerar todas as criaturas como formadas a partir da natureza; contestando certa opinião acerca da geração dos animais diz ele: “a não ser que já era inerente a todos os corpos animados alguma potência natural, como que de germes iniciais e como que présemeados de futuros animais que haveriam de nascer (...)"134. Dito de outro modo - que é opinião geral na interpretação de Agostinho - a evolução dos seres vivos não é outra coisa senão a concretização daquilo que desde sempre havia sido criado e bem fixado na espécie $^{135}$; portanto não há evolução ao modo de Darwin, com autonomia das espécies para “criarem" outras espécies, mas disposição das criaturas, inseridas desde sua origem, para darem nascimento a novas espécies, conforme o que Deus dispôs no inicio do mundo. Vejamos algumas outras formas de explicação das razões seminais: elas são forças imanentes de expansão da natureza ${ }^{136}$, germes destinados a se desenvolver ao longo do tempo ${ }^{137}$, cada coisa tem sua própria razão seminal desde a matéria primitiva, e vai dando o resultado do seu próprio germe quando se dão as condições causais requeridas ${ }^{138}$ e finalmente: a essência das rationes seminales é afim à umidade e contém uma determinada energia evolutiva e é semelhante aos números ${ }^{139}$ - a relação com os números é sugestiva, mas não conseguimos melhor explicação. O que não há dúvida é que, por mais que os intérpretes ortodoxos de Agostinho se esforcem, não há como não ver nas rationes semninales um certo tipo de evolucionismo - a não ser que se considere que existe apenas uma teoria da evolução, o que é pouco aceitável do ponto de vista da ciência. Vejamos só mais algumas "definições" das razões seminais: "Deus criou ao mesmo

\footnotetext{
${ }^{133}$ Com. Genesis 7, 21, 27, p. 258.

${ }^{134}$ Com. Genesis 3, 14, 23, p. 102.

135 Reale; Antiseri 453.

136 Thonnard 243.

137 Parain 1219.

${ }^{138}$ Fraile 216.

${ }^{139}$ Boehner; Gilson 179.
} 
tempo todas as coisas que seriam criadas em seus respectivos tempos pela ordem dos séculos fazendo com que se desenvolva no tempo tudo o que procede daqueles como que invólucros primeiros"140. "Foram essas razões inseridas antes de nascerem (...) por isso se chamam razões primordiais"141.

\section{O fim do mundo}

De acordo com a concepção judaica e cristã Agostinho não aceita a hipótese de um ciclo infinito de mundos iguais e repetitivos ${ }^{142}$. No entanto admite várias possibilidades: o poder de Deus é infinito e pode ter criado um número infinito de mundos que vêm à existência um depois do outro. Mais adiante explica de outra maneira: a expressão "séculos dos séculos" designa "os séculos ligados em conjunto numa cadeia contínua, e numa diversidade bem ordenada. Estas e outras hipóteses Agostinho considera possíveis; refuta várias vezes a ideia de mundos sucessivos repetidos e iguais; no entanto a argumentação contra a ideia dos mundos repetidos iguais não a vai buscar Agostinho à física ou à cosmologia, mas ao poder de Deus e à liberdade das almas ${ }^{143}$.

O mundo teve seis idades: de Adão a Noé, deste a Abraão, deste a David, deste até ao exílio de Babilônia, daqui até ao advento do Senhor Jesus Cristo. Agora estamos na sexta idade, no sexto dia (...) e depois deste dia e desta idade, o resto está prometido aos santos"144.

No Comentário ao Genesis contra os Maniqueus ${ }^{145}$ Agostinho desenvolve a ideia das idades do mundo, mas acrescenta-lhe a sétima, "que oxalá não nos alcance, se é que já não começou", que é a do juízo final. Ao final dessa explicação Agostinho faz algumas interpretações sobre os números referentes às idades do mundo: o número de gerações em cada idade, a multiplicação dos cinco sentidos pelo número dois do sexo humano (masculino e feminino) e ainda o dez, o sete, o catorze... ${ }^{146}$.

O mundo está velho e se acabando: "Tu te admiras de que o mundo está se acabando? Te admiras porque o mundo envelheceu (...) “. E compara: tal como um homem envelhece e está cheio de dores e maleitas, e sempre se queixando, assim está o mundo. "Na velhice

\footnotetext{
${ }^{140}$ Com. Genesis, 6, 6, 9, p. 210.

${ }^{141}$ Ib. 6, 11, 19, p. 219.

${ }^{142}$ Cidade de Deus 12, 19-20, Gulbenkian, 1125, NPNF 238/239.

${ }_{143}$ Cidade de Deus 12, 21, p. 1137.

${ }^{144}$ Sermões sobre o NT 75, 4, NPNF 6, 477 b.

${ }^{145}$ Comentário ao Genesis contra os Maniqueus 1, 23, 35-41, p. 534-540.

146 Ib. 540.
} 
do mundo Deus te enviou Cristo, para que ele te renove quando tudo está caindo (...). Cristo veio quando todas as coisas envelheceram, e as renovou (...). O mundo está declinando em direção à sua queda" (final) ${ }^{147}$.

O fim do mundo é significado pelo número oito: a revolução dos tempos se faz pela repetição daqueles sete dias da criação; quando não há mais repetição dos tempos para o tempo no sete, e o oito significa a ausência de tempo, o fim do tempo. O corpo, composto dos 4 elementos, está junto com a alma, representada pelo 3 (coração, alma e mente). $\mathrm{O}$ número oito é o que vem julgar essa união do 4 com o 3 . Mas como será o fím do mundo? “(...) este mundo passará por uma conflagração dos fogos dos mundos (...)"148. "Este mundo será queimado pelo fogo"149.

"O mundo acabará, mas tu continuarás" $" 150$. Os céus pereceram no dilúvio - mas só os céus próximos à Terra, onde voam os pássaros. Mas há céus muito acima desses, e Agostinho não quer ali discutir como é que esses céus vão perecer pelo fogo; apenas sabemos, diz ele, que no fim do mundo só Deus subsistirá ${ }^{151}$.

\section{Agostinho olha o mundo}

Agostinho olha e observa o mundo, está atento à configuração e eventos do universo; conhece razoavelmente muitas leis e relações que fazem do universo um cosmo, ou seja, um conjunto complexo e ordenado; mas o estudo desses objetos, leis, e relações para ele não é importante. Com exceção de um ou outro aspecto do universo, como a questão do tempo, Agostinho pouco se dedica a investigar e expor a ordem cósmica. É o que parece, mas não é bem assim.

Às vezes dá a impressão de que nunca se cansa de certos temas, como de fazer cálculos e "jogos" com números, ou discutir o que é o tempo. Mas outros temas é claro que não lhe interessam, como por exemplo: ao perguntar que espécie de fonte seria aquela que "regava toda a terra" 152 depois de demonstrar que na explicação não há nada contra a Escritura, diz: "Enfim, não nos cansemos mais""153.

\footnotetext{
${ }^{147}$ Sermões sobre as lições do NT 31, 8, NPNF 6, 356.

${ }^{148}$ Cidade de Deus 20, 16, Gulbenkian 2043, NPNF 2, 435.

149 Sermões sobre as lições do NT 31, 9, NPNF 9, 357.

150 Salmo 102, 26.

${ }^{151}$ Ex. Salmos 102, 30, NPNF 8, 502 b

${ }^{152}$ Gn 2, 6.

${ }^{153}$ Com. Genesis 5, 10, 26, p. 186.
} 
Nos seus escritos está dispersa uma visão de mundo, coerente, com alguns aspectos bem definidos e constantes - como a recusa da astrologia - mas não desenvolve uma teoria do cosmo como tal, em sua unidade e diversidade. Mesmo assim pode-se falar numa cosmologia de Agostinho, tendo em conta apenas o mundo material (inanimado), e deixando de lado a concepção espiritual do universo, e o sentido alegórico de tudo o quer acontece e existe no cosmo. Mas para ele essa cosmologia era secundária, e não deve absorver muito da sua atenção e preocupação. Quando Agostinho olha o universo, tanto o próximo como o distante, e fala do que lhe parece relevante, não é ingênuo: seu olhar é atento, mas sem ser nem teórico, nem crítico. Seu olhar sobre o mundo tem como primeiro objetivo encontrar alegorias, e espiritualizar o mundo físico pela constante referência a imagens que elevem a alma. "Uma vez que, neste conjunto orgânico do universo, o céu tem a maior figura (aparência) e a terra menos (...) dele se deduz que (Deus) se senta no céu e põe os pés na Terra. Porém espiritualmente a expressão céu significa as almas santas, e a terra significa as pecadoras" 154 . Outra interpretação alegórica da relação entre o céu e a terra vem adiante. Assim como no homem que cumpre a vontade do Pai, assim também na mulher que está comprometida com Ele. Porque Céu e Terra são adequadamente entendidos como se fossem homem e mulher: uma vez que a mulher dá frutos do céu que a fertilizam ${ }^{155}$.

\section{Comentários dispersos}

Para apreciar e entender melhor as opiniões e conhecimentos de Agostinho acerca do mundo material tentamos compará-las com as de outros autores da sua época, ou próximos; seriam interessantes, em particular, os neoplatônicos: Porfírio (c. 233-305), Jâmblico (c. 240-330), Proclo (412-485), e Damáscio (c. 470-544). Mas a investigação revelou-se, desde o início, difícil, arriscada, e pouco proveitosa. Haveria que tomar outro rumo, como comparar a cosmografia/cosmologia de Agostinho com a do Hexaemeron de Basílio Magno (c. 330-379), uma vez que a tradução latina do Hexaemeron, que Agostinho conhecia, já estava disponível desde $400^{156}$. Mas já vimos, em Agostinho, que grande parte dos seus conhecimentos sobre o universo não estão nos comentários ao

\footnotetext{
${ }^{154}$ Sermão da Montanha - De Sermone Domini in monte secundum Matthaeum. NPNF 6, Livro 1, cap. 17, item 53.

${ }^{155}$ Sermão da Montanha, II, cap. 6, item 24, p. 41.

${ }^{156}$ Por obra de Eustathius, cf. Inglebert 217.
} 
Genesis, mas dispersos em outras obras, e o mesmo teríamos que procurar em Basílio Magno. Tudo isso faz com que o capítulo, que poderias intitular-se "Atualidade dos conhecimentos de Agostinho com relação às ciências físicas e à filosofia da Natureza do seu tempo", se tornasse muito complexo; certamente haverá que deixar esse trabalho para outra ocasião, ou outro estudioso.

Mesmo assim, para não deixar passar essa oportunidade, consultamos alguns estudos amplos sobre ambiente, natureza, cosmografia, e cosmologia: Glacken, Inglebert, e o Visconde de Santarém, e neles encontramos algumas opiniões e observações sobre Agostinho, que nos pareceram relevantes.

O Visconde de Santarém, (1791-1856) Manuel Francisco de Barros e Sousa de Mesquita Macedo Leitão e Carvalhosa, historiador, diplomata e político português, viveu no Rio de Janeiro e em Paris, entre outros lugares, e escreveu diversas obras sobre os descobrimentos portugueses; o seu estudo sobre a cosmografia da Idade Média, em três volumes, serve de apoio técnico a esses estudos, e tem como título completo (tradução nossa):

Ensaio sobre a história da Cosmografia e da Cartografia durante a Idade Média e sobre os progressos da Geografia conforme as grandes descobertas do século XV, para servir de introdução e de explicação ao atlas composto de mapas mundi e de portulanos, e de outros monumentos geográficos, desde o século VI da nossa era até ao XVII.

Não é, pois, um autor, e uma obra, onde haja que esperar citações ou referências a Agostinho de Hipona, mas elas estão lá, embora poucas. Falando de Jacques de Vitry (c. 1160-1240) diz o autor que entre os autores que ele cita está Santo Agostinho, mas não dá mais explicação. O contemporâneo dele Guilherme de Jumièges (c. 1000-1070) também o cita, e o famoso De Imagine Mundi de Honoré d'Autrun (c. 1080-1151) menciona a cosmografia de Agostinho ${ }^{157}$. Nicolau d'Oresmes (1320-1382), cartógrafo de Carlos V, cita Agostinho para confirmar que não pode haver antípodas, mas enquanto o bispo de Hipona dá argumentos pela dificuldade da viagem, Nicolau diz que a existência de antípodas seria contra a fé cristã ${ }^{158}$. Continuando na questão da esfericidade da terra o Visconde parece mal informado: diz que Raban Mauro (c. 780-856) cita Agostinho para garantir a opinião de que a Terra é quadrada, pois, segundo a Bíblia (diz R. Mauro) a Terra não pode ser redonda ${ }^{159}$; mas já vimos que essa não era a opinião de Agostinho. $\mathrm{O}$

\footnotetext{
${ }^{157}$ Santarém 69-71.

158 Santarém 142.

159 Santarém 244-245 e 410.
} 
Visconde afirma ainda, citando a Cidade de Deus ${ }^{160}$, que Agostinho conhecia as propriedades magnéticas do ferro, mas não conhecia a bússola ${ }^{161}$. É interessante notar que Agostinho, depois de descrever os efeitos magnéticos do ferro ${ }^{162}$ continua: "Contei o que eu próprio vi", o que confirma os dois modos de aproximação ao mundo material que encontramos em Agostinho: o estudo da bibliografia existente, e particularmente da Bíblia, e a observação atenta.

Inglebert, na sua ampla obra sobre a apropriação cristã das ciências antigas, cita Agostinho com muita frequência (cerca de 50 vezes), embora mais nas questões antropológicas e teológicas (ou, mais geralmente, de Teodiceia). Começando pela questão controversa do Visconde de Santarém, a da esfericidade da Terra, Inglebert entende, como nós, que Agostinho defende o modelo esférico, embora perante a Bíblia ele ache que ambos os modelos sejam compatíveis ${ }^{163}$. Também numa interpretação que entendemos seja correta o comentarista diz que sobre a questão de os astros serem, ou não, seres vivos, Agostinho não toma partido ${ }^{164}$. Outras observações e opiniões de Agostinho acerca do mundo material são citadas brevemente, sem que o comentarista lhes dê maior importância, por isso apenas indicamos os temas: os rios subterrâneos ${ }^{165}$; se as águas superiores serviam para temperar o calor dos astros ${ }^{166}$; o que é que segura as águas nos céus superiores $^{167}$; a recusa e o combate à astrologia ${ }^{168}$; a previsão dos eclipses ${ }^{169}$; sobre as acusações de magia feitas aos cristãos ${ }^{170}$; a luz da lua ${ }^{171}$; escatologia ${ }^{172}$; a recusa da existência do tempo mítico ${ }^{173}$. Mas no problema das águas superiores, as que estão acima do firmamento, o comentário de Inglebert é um pouco mais longo ${ }^{174}$. Há ainda referência a opiniões teológicas importantes e recorrentes em Agostinho, como a inutilidade de tentar resolver problemas referentes aos astros ${ }^{175}$ quando se deixa, como secundário, o

\footnotetext{
${ }^{160}$ Cidade de Deus 21, 4.

161 Santarém 289.

162 Gulbenkian 2136-2137.

163 Inglebert 47, e nota, e 91.

16435 , nota 42 .

$16589-90$.

166213.

167216.

$168227,229,232,250$.

169256 nota 302 .

170230 .

171251.

172361 .

$173373-374$

174218.

175252.
} 
conhecimento de Deus; bem como sobre o método de resolver dúvidas ${ }^{176}$. Mas, como dissemos no início, e como é próprio da obra de Inglebert, Agostinho é mais citado sobre questões referentes à antropologia, à sociologia, à história, à linguística, à relação entre fé e ciência, filosofia e heresia, à diferença entre gnósticos e maniqueus, ao uso cristão das ciências profanas (com reticências), às heresias, à teologia da história, ao fim do mundo e à ressurreição dos corpos. No total das cerca de 50 citações, aquelas que se referem a questões do mundo material, ou físico (não vivo), são aproximadamente um terço, o que, para um autor, como Agostinho, de quem geralmente só se estuda a Teologia, é bastante significativo.

O tema mais importante para Glacken é a relação do ser humano com a natureza, principalmente viva, ou biológica, e nesse sentido vai a sua afirmação sobre os Santos Padres:

Os primeiros Padres da Igreja, incluindo Agostinho, nas suas obras apologéticas, isto é, no esforço por afastar os ataques pagãos ao cristianismo, não negligenciaram as evidências da natureza, com o objetivo de provar a superioridade da religião cristã sobre a pagã, e a realidade viva dos propósitos divinos ${ }^{177}$.

No que se refere à relação entre Deus (os deuses, as divindades) e o mundo físico, a doutrina cristã é muito superior à da civilização grega e romana, em particular no que se refere à criação, em que Agostinho é especialmente citado ${ }^{178}$. Glacken destaca o fato de Agostinho rejeitar a doutrina de que a origem da diversidade do universo estaria na sua decadência ${ }^{179}$.

Glacken expõem ${ }^{180}$ com algum relevo a explicação de Agostinho acerca da criação, comparando-o a Filão de Alexandria; e dá atenção ao interesse de Agostinho pelos números ${ }^{181}$, citando: "Não devemos menos prezar a ciência dos números, a qual em muitas passagens das Sagradas Escrituras se mostra prestando bons serviços ao intérprete cuidadoso"182.

No que se refere à astrologia Glacken contrasta Agostinho com a escolástica, na pessoa de Alberto Magno. Enquanto a maioria dos Padres, e Agostinho em particular, rejeitavam a astrologia como sendo uma espécie de idolatria, e uma negação do livre arbítrio ${ }^{183}$, Alberto defende que a influência dos astros é como um instrumento da criatividade divina;

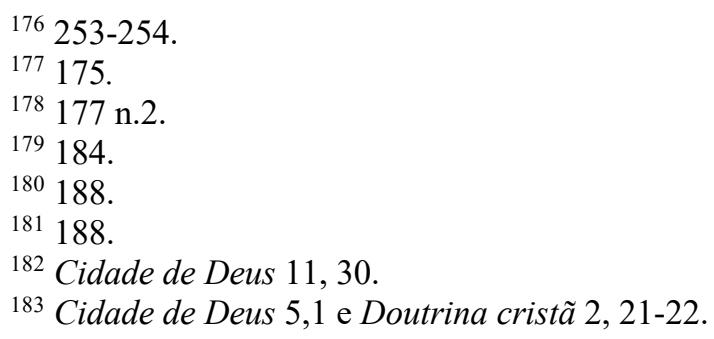


existem muitas energias cósmicas que influenciam a ação humana, diz Alberto, e quem as conhece pode intensificá-las, ou se precaver contra elas ${ }^{184}$.

Outra questão é a do relacionamento físico do ser humano com o mundo. Glacken ${ }^{185}$ lembra que Agostinho elogia as artes ${ }^{186}$ e que insiste, ao tratar da vida dos monges ${ }^{187}$, que eles devem realizar trabalho manual ${ }^{188}$.

Mas Glacken dedica a Agostinho todo um capítulo ${ }^{189}$ relativamente extenso (e prolongado). Adverte ${ }^{190}$ que os comentários de Agostinho ao Genesis são menos literais e mais alegóricos do que o Hexaemeron de Basílio Magno e que nele o mundo material, embora inferior, é descrito como belo e digno de respeito. O mundo, diz Agostinho, não é mau, os homens ímpios é que fazem o mundo mau ${ }^{191}$; critica, porém, a ideia da Terra Mãe, não só porque ela não é criadora, mas porque seus seguidores, e os sacerdotes que se dedicam ao seu culto são efeminados ${ }^{192}$. Agostinho continua ${ }^{193}$, e Glacken citando ${ }^{194}$, que existe uma ordem na natureza em que alguns seres são superiores a outros, e há uma ordem de valores humanos, e essas ordens não coincidem.

Passa depois ${ }^{195}$ aos diversos graus de ser entre as criaturas vivas, destacando a opinião de Agostinho de que devemos apreciar as coisas da natureza por si mesmas, e não pelo seu valor utilitário em relação aos seres humanos ${ }^{196}$. Por isso, embora o amor de Deus, simbolizado por Jerusalém, seja preferível ao amor do mundo, representado por Babilônia, há que ter em conta que Babilônia não é inútil ${ }^{197}$. E reforça ${ }^{198}$ : quantas coisas que parecem insignificantes são dignas de admiração:

Em todos os variados movimentos da criação, em que está a obra de Deus, há algum que não seja admirável? Contudo, por estarmos acostumados a ver tais maravilhas elas nos parecem pequenas. Quantos pequenos objetos nós pisamos, os quais, se os examinássemos com cuidado, despertariam o nosso espanto! ${ }^{199}$.

\footnotetext{
184201 e 266.

185 299-300.

${ }_{186}$ Cidade de Deus 22, 24.

187 304-306.

${ }^{188}$ Retractationes, passim.

189 196-204.

190196.

191197.

$192 \mathrm{Ib}$.

${ }^{193}$ Cidade de Deus 11, 16.

194198.

195198.

${ }^{196}$ Cidade de Deus 11,16 e 12, 4.

${ }_{197}$ Cidade de Deus 14, 28.

198199.

${ }^{199}$ Carta 137, 3, 10, NPNF 477.
} 
E Agostinho insiste: o mundo que Deus criou é belo ${ }^{200}$; prossegue explicitando as relações entre o Criador e as criaturas, e afirmando com veemência: "para que tu te aproximes e o conheças Ele dispôs diante dos teus olhos as coisas que fez" ${ }^{201}$.

Glacken conclui o capítulo, e nós adotamos esta sua conclusão: “Os vários temas que Agostinho desenvolve constituem uma síntese cristã e uma visão filosófica do ser humano na natureza" 202 .

\section{Referências}

\section{Textos de Agostinho:}

A Doutrina Cristã. São Paulo: Paulinas, 1991.

De Doctrina Christiana. NPNF 2, 513-597.

Confissões. Petrópolis: Vozes, 1988.

A Cidade de Deus. Lisboa: Fundação Calouste Gulbenkian, 1991-1995, 3 vols. Sobre a música. Campinas: CEDET/Ecclesiae, 2019.

Diálogo sobre a Ordem. Lisboa: Imprensa Nacional/Casa da Moeda, 2000.

A Natureza do Bem. Porto: Fundação E. A. Almeida, 1992.

Solilóquios e a Vida Feliz. São Paulo: Paulus, 1998.

Comentários ao Gênesis. São Paulo: Paulus, 2005.

City of God. Peabody: Hendrickson, 1995.

The Enchiridion. Peabody: Hendrickson, 1995.

On the Profit of Believing (De Utilitate credendi). NPNF 3, 347-366.

The Advantage of Believing. Washington: The Catholic University of America Press, 1992 (1947).

Proceedings Against Pelagius (De Gestis Pelagii). NPNF 5, 177-212.

Sermons on selected Lessons of the New Testament. NPNF 6, 237-545.

\footnotetext{
2002.

201204.

202201.
} 
Expositions on the Book of Psalms. Editado a partir da tradução de Oxford por Cleveland Coxe. NPNF 1. série, vol. 8 Peabody, Hendrickson, 1995.

The Harmony of the Gospels (De Consensu Evangelistarum). NPNF 6, 65-236.

\section{Bibliografia geral}

BAUCHWITZ, Oscar Federico (org). O Neoplatonismo. Natal: Argos, 2001.

BOEHNER, Philotheus; GILSON, Étienne. História da Filosofia Cristã. 5. ed. Petrópolis: Vozes, 1991.

FERNANDEZ, Clemente. Los Filósofos medievales. Selección de textos. Madrid: BAC, 1979.

FRAILE, Guillermo. Historia de la Filosofía. 2. ed. Madrid: BAC, 1966.

PARAIN, Brice. Histoire de la Philosophie, 1. Paris: Gallimard, 1969.

REALE, Giovanni; ANTISERI, Dario. História da filosofia. Vol. 1. São Paulo: Paulus, 1990.

THONNARD, François-Joseph. Compêndio de História da Filosofia. Sociedade São João Evangelista, 1953.

\section{Comentários e consulta específica}

GLACKEN, Clarence J. Traces on the Rhodian Shore. Berkeley: University of California Press, 1967.

INGLEBERT, Hervé. Interpretatio Christiana. Paris: Institut d'Études Augustiniennes, 2001.

LE COMTE DE SANTAREM. Essai sur l'histoire de la cosmographie et de la cartographie pendant le Moyen Âge. Vol. 1 e 3. Paris: Maulde et Renoue, 1849-1852.

LUPI, João. A cosmologia de Plotino. In: BAUCHWITZ 2001, 183-190.

MARITAIN, Jacques. La Philosophie de la Nature. Paris: Téqui, sd.

RÊGO. Marlesson Castelo Branco do. O Conceito de Natureza em Santo Agostinho. Tese de doutorado. Programa de Pós-Graduação Interdisciplinar em Ciências Humanas. Universidade Federal de Santa Catarina. Florianópolis, 2015.

ROUSSEAU, Jean-Jacques. Emílio, ou da Educação. São Paulo: União Europeia, 1973.

STUMP, Eleonore; KRETZMANN, Norman (ed.). The Cambridge Companion of Augustine. Cambridge: Cambridge University Press, 2001. 